\title{
Perceptual Judgement of Smartphone Visual Aesthetics among Students of Moshood Abiola Polytechnic, Abeokuta, Ogun State, Nigeria
}

\author{
Tope Israel Ibiwoye, Oladunni Philip Adesiji \\ Department of Industrial Design, Federal University of Technology, Akure, Ondo State, Nigeria \\ Email: topibiwoye@yahoo.com, tiibiwoye@futa.edu.ng
}

How to cite this paper: Ibiwoye, T. I., \& Adesiji, O. P. (2020). Perceptual Judgement of Smartphone Visual Aesthetics among Students of Moshood Abiola Polytechnic, Abeokuta, Ogun State, Nigeria. Art and Design Review, 8, 159-169.

https://doi.org/10.4236/adr.2020.83012

Received: June 11, 2020

Accepted: June 19, 2020

Published: July 13, 2020

Copyright $\odot 2020$ by author(s) and Scientific Research Publishing Inc. This work is licensed under the Creative Commons Attribution International License (CC BY 4.0).

http://creativecommons.org/licenses/by/4.0/

\begin{abstract}
Visual aesthetics had always referred to the beauty or pleasant appearance of a thing. Being a visual gadget that has some visual properties in its operation, the smartphone has caught the interest of visual research to probe into the attractive tendencies of its Graphical User Interface, and design layout. The study therefore examined the perception judgement of the visual aesthetic features of smartphones among the students of Moshood Abiola Polytechnic, Abeokuta, Ogun State, Nigeria, paying attention to demographic differences in visual aesthetic judgement among students in the study domain. Sample size of 380 was taken as sample from 27,000 students. Systematic random sampling was used, Likert Scale was used to rate users' perception of the visual aesthetics of their smartphones and the result was analyzed using descriptive statistics. The result showed greater percentages of the demographic variables showing a significant relationship with visual aesthetics perception among the respondents; while twelve (12) cases show large effect, only six (6) cases show exceptions with no significant effect relationship. This creates an inference that smartphone visual aesthetics presents an inspirational platform for its desired and continued use among students of higher institutions.
\end{abstract}

\section{Keywords}

Perceptual Judgement, Smartphone, Visual Aesthetics, Demography

\section{Introduction}

Smartphone provides interactive features for increasing wider users around the world. It has become an integral part of everyday student's life. Frommer (2011) projected that mobile phone sales are expected to outstrip PC sales and the 
smartphone users worldwide will triple from 165 million to over 500 million within the few years. Developments of the mobile phones popularly called smartphones allow users to perform activities such as sending text messages, calling, chatting, opening documents, checking e-mails, browsing internet and downloading files in a very convenient way. Smartphone technology provides immense benefits for users as they access and disseminate information rapidly (Jollie \& Liezel, 2016).

Resultant effects of the innovative achievements in smartphone technology have changed the face of formal teaching and learning processes, while it has simplified sourcing for information, its storage, retrieval, and many others. It has also exposed the users to distraction. Scholars who studied different areas of Information and Communication Technology (ICT) have suggested that the heavy use of technology for recreational purposes is highly correlated with reduced academic performance (Kubey, Lavin, \& Barrows, 2001). Visual appeal may be a major bait of distraction in prominent usage of smartphone in satisfying affective needs at the expense of learning particularly among the youth.

Aesthetics is the area of artistic design that seeks to communicate primarily through the eyes, mind, brain and thoughts of the consumers of products. Visual Aesthetic, this refers to the beauty or the pleasing appearance of things. In studying aesthetics in the human-computer interaction, smartphone takes a prominent role in the present discourse among the youths with respect to academic pursuit in the mind of all stakeholders in the educational and industrial design fields. Smartphone visual aesthetics considered as the features involving its layout, navigation, graphical user interface (GUI) elements (such as windows i.e. app workspace; buttons, menus and etcetera, with which users interact through the use of one or several modalities such as mouse, keyboard, touchscreen, voice recognition system etc.) and interactivity of the screen.

The study therefore aimed at investigating how students perceive the visual aesthetics of their smartphones; the study further probed into the effect of demography on student visual aesthetic judgement, making use of the following research questions to guide it operation: One; what is the perceptual judgement of smartphone visual aesthetics among students of Moshood Abiola Polytechnic, Abeokuta? Two; is there any demographic differences in visual aesthetic judgement among undergraduate students?

\section{Literature Review}

\subsection{An Overview on Aesthetics}

Aesthetic is a derivative of a Greek word, aisthanesthai meaning to perceive. It is said to reflect to a dynamic and complex set of relationships in human sensory perception. These sensory perceptions are attributed to feeling toward works of art, which could be liberal or visual. It also guides the perspicacity of subjective judgment associated with perceiving these beauty created (Lopes, 2015). The term aesthetic is an interesting phenomenon that cut across different sphere of 
life. Brachmann, and Redies, (2017) note that aesthetics has been at the centre of long-standing debates in the field of philosophy and psychology. It is generally believed in psychology, that aesthetic experience results from an interaction that exudes between perception, cognition, and emotion. It is observed that by experimental means, this trio has been studied in the field of "experimental aesthetics", which is focused at gaining a better understanding of how aesthetic experience relates to fundamental principles of human visual perception and brain processes. Recently, researchers in computer vision have also gained interest in the topic, giving rise to the field of "computational aesthetics" (Brachmann \& Redies, 2017).

\subsection{Aesthetics, Media Consumption and Communication Technology}

The aesthetic aspect of media consumption helps to discover and monitor the different directions of development of the "public sphere" where individual freely come together to discuss and identify societal problem. The diverse opportunities exhibited in the present-day communicative field coupled with the "user-friendly" facilitated technologies of producing multimedia has shed light on users' interests: aesthetic traits of communication, including "emotional turn" develop toward an "aesthetically rich environment", where one can find "excitements" around gustation, haptics, olfaction and other types of sensation, including never ending searches of new sensations (Zagidullina, 2019).

It has been indicated that communication technologies had been riding on the shoulder of developments in social media, this trend however could be vice versa. The relationship of the duo is also helping to develop personal creative needs. This is achieved by expediting the creative process using different types of multimedia messages: video, audio, images etcetera. The media aesthetic component operates as a virtual species in a natural environment which has the propensity to attract, protect, provoke and stimulate, trying to win the competition with a limited resource of public attention (Zagidullina, 2019). Sherry Turkle, a psychologist with about twenty years' experience in researching into the behaviour of social media in her book "Alone Together" laments on the speed with which people are eager and willing to relinquish real or natural connections in favour of all sorts of intangible or virtual means of connection or association. Sadly enough, it is not that people are willing to sacrifice a true or natural connection for false comfort from robots that have been programmed to meet the gratification need. However, the social isolation keeps increasing (Edelson, 2011 Turkle, 2011; Ibiwoye, 2017).

As media aesthetics can be taken in its perceptive aspect, it is important to describe this process from the perspective of its tangibility as "substance" for vision, audition, touch, gustation, and olfaction. The visual and auditory elements of communication are well researched upon from their aesthetic aspect, while other sensations in aesthetic "domain" (Zagidullina, 2019). 


\subsection{Smartphone Visual Aesthetics}

It is obvious that the design of a product should reflect the desired image of the product. Solid, fast, youth attractive, high quality, feminine, masculine; all these attributes can be reflected and enhanced through innovative design. Yigit and Halil (2015) submit that, one of the most effective ways of differentiating products amidst competitors is using aesthetics. Visual aesthetics of products creates value for consumers. Visual aesthetics create significant value for product and makes it more special. In the opinion of Shrestha (2016), among all five senses, visual aspects is very essential for marketers in every marketing form, may it be store or package designing, or advertising. Visual elements can be interpreted into various messages. Colour is the best example of visual aspects which can interpret and convey several meanings and emotions. Colour speeds search times and are basically used to attract consumers. The extracted parameters as adopted from Mathieu and Jean (2014) are:

- Screen resolution;

- Learnability-easy to understand;

- Emotional effects;

- Configuration options and shortcuts;

- Navigation and user control;

- Visibility and system status;

- Layout of smartphone interface.

These seven parameters were used to generate a 10 -item instrument to measure users' perceptual judgement of their smartphone visual aesthetics in this study, see Table 2.

\subsection{Role of Visual Aesthetics in Human-Computer Interaction}

The importance of visual aesthetics to the field of Human Computer Interaction, $\mathrm{HCI}$ can be discussed from various perspectives among which are design perspective, the psychological perspective, and the practical perspective (Tractinsky \& Hassenzahl 2005). The design perspective is first, the implication to recognise that aesthetics constitutes an important and integral part of any design discipline. The importance of aesthetics increases as the interface between the artefact and the affected people (for instance, in terms of visual saliency, length of interaction or co-habitation) becomes more comprehensive. The second implication is that visual aesthetics is often related to other design aspects. Thus, not only should we not worry about trading off aesthetic and other qualities of interactive systems; we should embrace aesthetics as a dimension that augments other aspects of the design and the overall interactive experience.

The psychological perspective the emergence of visual aesthetic research in HCI, it had its roots in the "positive psychology" movement (Seligman \& Csikszentmihalyi, 2000) that called for a shift towards dealing with human strengths and well-being instead of with weaknesses and their remedies. This sentiment was enthusiastically embraced in the field of $\mathrm{HCI}$ in the context of studying the user experience (Hassenzahl \& Tractinsky, 2006; Law \& Schaik, 2010). 


\subsection{Differences in Aesthetic Judgement Based on Demographics}

In a study based on info-graphics, Lane, Katharina and Remco (2015) found that demographic factors such as gender, age, and education level impact perceived appeal; the study reported "colourfulness" and visual complexity explain roughly half of the variance in people's judgements of the appeal of websites and are considered some of the most salient features that humans perceive within the first $500 \mathrm{~ms}$ with varying ratings across the demographic variables. Findings from Lane et al indicates that females prefer more colourful, yet less complex info-graphics than males, while males generally prefer fewer and less saturated colours and are relatively unaffected by different levels of complexity. Preference for simple info-graphics slightly increases with age and education level. Thus, the general preference for colourful info-graphics with few text and image areas might appeal to most participants in our sample, but not to all.

On gender-based variation, Moss (2003) took a swipe at physiological factors, the study submits thus. Men's preference for three dimensional vision may be related to the fact that men's eyes are 4 centimetres further apart than women's, as well as to the fact that the part of the brain used for three-dimensional vision, the inferior parietal lobe, is larger in men than in women. Women's instinct for colour on the other hand, may be related to the lower incidence of colour blindness amongst females than males. On average, $8 \%$ of males suffer from colour blindness as compared with $0.5 \%$ of females. Some might see these attributes as the outcome of an evolutionary process which placed a premium in women on the development of close-up skills, skills not requiring superior 3-dimensional vision (skills such as food gathering, child rearing and the construction of the domestic foyer and its contents); while men's superior 3-dimensional skills and preference for dark colours could be seen as an adaptation to the need to stalk and hunt prey at a distance (note that colours look dark on the horizon).

In similar vein, Shih-Yung and Hsiu-Tyan (2014) in a study evaluating aesthetic response of architectural space, it is asserted that gender, grade and major do have certain effects on aesthetic evaluation; moreover, it also verified that professional training brought significant differences to aesthetic evaluation.

In order to be able to adequately examine the subject under consideration and relate with relevant authorities in the field of visual aesthetics and visual perceptual judgement, the foregoing were reviewed. Therefore in summary, the review had spanned from the overview on aesthetics, delineating the general view of aesthetics. The media consumption and communication technology elements of aesthetics were also reviewed, showing a kneaded connection of the duo. The smartphone visual aesthetics played a dominant role in the review as well as the role of visual aesthetics in Human-Computer Interaction which described the pivot of the study. The review concludes with a vital aspect of the study that accentuates the relationship between aesthetic judgement and sample demographics. 


\section{Methodology}

\subsection{Research Design}

Descriptive research of survey type, which involves analyses, interpretations, comparisons, identification of trends and relationships (Neeru, 2012) was adopted for this study. As a survey research, structured questionnaire was used as inventory tool to obtain data from the sample audience. The questionnaire was in two parts. The first part addresses the demographic characteristics of the respondents while the second part addresses the views of the respondents on the issues raised in the set objectives and research questions. The questionnaire was constructed based on the perception judgement of visual aesthetics; it measures users' satisfaction according to their self-reported judgement of satisfaction.

The students of Moshood Abiola Polytechnic, Abeokuta, numbering 27,000 is population for this study, cutting across all the five (5) faculties of the institutions in order to ascertain holistic responses from the target population. The instrument was collected back after the respondents have filled them out. Purposive sampling was adopted in the sample selections; this means that those qualified to participate in this research need to own a smartphone, therefore, the questionnaire was given to students who owns a smartphone.

\subsection{Sample Size}

This refers to the number of items to be selected from the universe to constitute a sample. It should be optimum. To obtain an optimum sample that fulfils the requirements of efficiency, representativeness, reliability and flexibility, the sample size was determined with the use of The Cochran equation (Cochran, 1963):

$$
\begin{gathered}
n=\frac{n_{0}}{1+\frac{\left(n_{0}-1\right)}{N}} \\
n=\frac{385}{1+\frac{(385-1)}{30000}}=\frac{385}{1.014}=379.7=380
\end{gathered}
$$

\section{Results and Findings}

\section{Demographic Data of Respondents}

Based on the calculated sample size, a total of three hundred and eighty (380) questionnaires were distributed to the respondents out of which three hundred and fifty-four (354) were returned, representing $92.2 \%$ of the total. The demographic variables included in the questionnaire are name (optional), age range, gender, marital status, academic level in school, and course of study. Other parameters in the general statistics are the brand of respondent's smartphone and the operating system installed on it. Table 1 gives a breakdown of the demography as follow: The response statistics shows $15.3 \%$ representing a total of 54 students who participated in the study are less than 20 years, 195 students out of the total 354 (55\%) were aged between 20 - 25 years, while 105 students (29.7\%) are 
between 26 - 30 years old, and no participant is above 30 years. The total population of male respondents are 46.6\%, 165 students while the female -students were represented with 189 students which translates to $53.4 \%$. The marital status of the respondents show that a whopping 336 students (94.9\%) are single while only 18 (5.1) of the total number are married, data obtained shows that there is no respondent who is separated, divorced or widowed. The participating students in ND classes are 189 students (53.4\%) while 165 students (46.6\%) who are in HND classes in the institution as contained in.

Table 2 shows the students' high satisfaction rate with the visual aesthetics of their smartphone has mean scores of 3.64 - 4.95 under Agree and Strongly Agree responses were expressed in six (6) out of the ten (10) visual aesthetics questions. The Table also shows that layout, navigation and user control aspect has the highest mean score (Agree and Strongly Agree) overall in the aesthetic judgements for:

$1^{\text {st }}$ - I am always excited to do one thing or the other on my smartphone because of its attractive features.

$2^{\text {nd }}-$ My smartphone features are easy to understand.

$3^{\text {rd }}$ - My smartphone enhance fast navigation and adequate user control.

Table 1. Respondents' demographic information.

\begin{tabular}{|c|c|c|}
\hline & Response & Frequency (\%) \\
\hline & Less than 20 & $54(15.3 \%)$ \\
\hline \multirow{4}{*}{ Age } & $20-25$ years & $195(55.0 \%)$ \\
\hline & $26-30$ years & $105(\%)$ \\
\hline & 30 years and above & $0(0 \%)$ \\
\hline & Total & $354(100 \%)$ \\
\hline \multicolumn{3}{|l|}{ Gender } \\
\hline & Male & $165(46.6 \%)$ \\
\hline & Female & $189(53.4 \%)$ \\
\hline & Total & 354 \\
\hline \multicolumn{3}{|c|}{ Marital Status } \\
\hline & Single & $336(94.9 \%)$ \\
\hline & Married & $18(5.1)$ \\
\hline & Separated & $0(0 \%)$ \\
\hline & Divorced & $0(0 \%)$ \\
\hline & Widowed & $0(0 \%)$ \\
\hline & Total & 354 \\
\hline \multicolumn{3}{|c|}{ Academic level } \\
\hline & ND & $189(53.4 \%)$ \\
\hline & HND & $165(46.6 \%)$ \\
\hline & Total & 354 \\
\hline
\end{tabular}

(Source: Researchers, 2017). 
Table 2. Perceptual rating of the smartphone visual aesthetics.

\begin{tabular}{|c|c|c|c|c|c|c|c|c|}
\hline & & $\begin{array}{l}\text { SD } \\
\text { Freq }(\%)\end{array}$ & $\begin{array}{l}\text { D } \\
\text { Freq (\%) }\end{array}$ & $\begin{array}{l}\mathrm{U} \\
\text { Freq (\%) }\end{array}$ & $\begin{array}{l}\text { A } \\
\text { Freq (\%) }\end{array}$ & $\begin{array}{l}\text { SA } \\
\text { Freq (\%) }\end{array}$ & Mean & Rank \\
\hline 1. & $\begin{array}{l}\text { The screen resolution of my smartphone is } \\
\text { excellent. }\end{array}$ & $\begin{array}{l}12 \\
(2.5)\end{array}$ & $\begin{array}{l}24 \\
(6.8)\end{array}$ & $\begin{array}{l}21 \\
(5.9)\end{array}$ & $\begin{array}{l}177 \\
(50)\end{array}$ & $\begin{array}{l}123 \\
(34.7)\end{array}$ & 4.08 & 6 \\
\hline 2. & My smartphone features are easy to understand & $\begin{array}{l}03 \\
(0.8)\end{array}$ & $\begin{array}{l}12 \\
(3.4)\end{array}$ & $\begin{array}{l}18 \\
(5.1)\end{array}$ & $\begin{array}{l}183 \\
(51.7)\end{array}$ & $\begin{array}{l}138 \\
(39)\end{array}$ & 4.25 & 2 \\
\hline 3. & $\begin{array}{l}\text { I am always excited to do one thing or the other on } \\
\text { my smartphone because of its attractive features. }\end{array}$ & $\begin{array}{l}06 \\
(1.7)\end{array}$ & $\begin{array}{l}09 \\
(2.5)\end{array}$ & $\begin{array}{l}18 \\
(5.1)\end{array}$ & $\begin{array}{l}165 \\
(46.6)\end{array}$ & $\begin{array}{l}156 \\
(44)\end{array}$ & 4.95 & 1 \\
\hline 4. & $\begin{array}{l}\text { My smartphone allows configuration options and } \\
\text { shortcuts. }\end{array}$ & $\begin{array}{l}15 \\
(4.2)\end{array}$ & $\begin{array}{l}12 \\
(3.4)\end{array}$ & $\begin{array}{l}09 \\
(2.5)\end{array}$ & $\begin{array}{l}201 \\
(56.8)\end{array}$ & $\begin{array}{l}117 \\
(33.1)\end{array}$ & 4.11 & 4 \\
\hline 5. & $\begin{array}{l}\text { My smartphone enhance fast navigation and } \\
\text { adequate user control. }\end{array}$ & $\begin{array}{l}06 \\
(1.7)\end{array}$ & $\begin{array}{l}18 \\
(5.1)\end{array}$ & $\begin{array}{l}09 \\
(2.5)\end{array}$ & $\begin{array}{l}204 \\
(57.6)\end{array}$ & $\begin{array}{l}117 \\
(33.1)\end{array}$ & 4.15 & 3 \\
\hline 6. & $\begin{array}{l}\text { My smartphone allows quick visibility and system } \\
\text { status. }\end{array}$ & $\begin{array}{l}12 \\
(3.4)\end{array}$ & $\begin{array}{l}09 \\
(2.5)\end{array}$ & $\begin{array}{l}15 \\
(4.2)\end{array}$ & $\begin{array}{l}213 \\
(60.2)\end{array}$ & $\begin{array}{l}105 \\
(28.7)\end{array}$ & 4.10 & 5 \\
\hline 7. & $\begin{array}{l}\text { The layout of my smartphone interface is } \\
\text { pleasantly varied. }\end{array}$ & $\begin{array}{l}09 \\
(2.5)\end{array}$ & $\begin{array}{l}21 \\
(5.9)\end{array}$ & $\begin{array}{l}30 \\
(8.5)\end{array}$ & $\begin{array}{l}210 \\
(59.3)\end{array}$ & $\begin{array}{l}84 \\
(23.7)\end{array}$ & 3.96 & 7 \\
\hline 8. & $\begin{array}{l}\text { The aesthetic features of my phone influenced my } \\
\text { choice at point of purchase }\end{array}$ & $\begin{array}{l}21 \\
(5.9)\end{array}$ & $\begin{array}{l}39 \\
(11)\end{array}$ & $\begin{array}{l}39 \\
(11)\end{array}$ & $\begin{array}{l}162 \\
(45.8)\end{array}$ & $\begin{array}{l}93 \\
(26.3)\end{array}$ & 3.75 & 9 \\
\hline 9. & $\begin{array}{l}\text { I am always inspired to use my smartphone } \\
\text { frequently because it is visually appealing. }\end{array}$ & $\begin{array}{l}09 \\
(2.5)\end{array}$ & $\begin{array}{l}27 \\
(7.6)\end{array}$ & $\begin{array}{l}36 \\
(10.2)\end{array}$ & $\begin{array}{l}177 \\
(50)\end{array}$ & $\begin{array}{l}102 \\
(28.8)\end{array}$ & 3.96 & 7 \\
\hline 10. & $\begin{array}{l}\text { The aesthetic features of my smartphone suit my } \\
\text { cognitive and affective needs. }\end{array}$ & $\begin{array}{l}24 \\
(6.8)\end{array}$ & $\begin{array}{l}48 \\
(13.6)\end{array}$ & $\begin{array}{l}36 \\
(10.2)\end{array}$ & $\begin{array}{l}168 \\
(47.5)\end{array}$ & $\begin{array}{l}78 \\
(22)\end{array}$ & 3.64 & 10 \\
\hline
\end{tabular}

Key: Strongly disagree-SD, Disagree-D, Undecided-U, Agree-A, Strongly agree-SA (Source: Researchers, 2017).

This creates an inference that smartphone visual aesthetics presents an inspirational platform for its desired and continued use among students of higher institutions; this agrees with the finding of Gharaibeh, and Arshad (2018) that visual aesthetics is an effective determinant in the adoption of mobile banking service (Table 3).

A chi-square test for independence (with Yates Continuity Correction) indicated significant association between the listed demographic variables; age, gender, marital status, academic level and course of study. Based on Cohen (1988) criteria for determining the effect level of Pearson chi-square value:

0.1-Small effect, 0.3-Medium effect, 0.5-Large effect

Greater percentages of the demographic variables show significant relationship with visual aesthetics perception among the respondents; while twelve (12) cases show large effect, only six (6) cases show exceptions with no significant effect relationship.

From the foregoing, there is significant difference in visual aesthetic judgement based on demographics of undergraduate students, however, "My smartphone enhance fast navigation and adequate user control" which measures navigation and user control parameter returns no significant difference among the demographic variables; this implies that all the participants in the study desires clear-cut ease in usage of their smartphones irrespective of their status. 
Table 3. Demographic differences in visual aesthetic judgement among undergraduate students.

\begin{tabular}{|c|c|c|c|c|c|c|}
\hline & & Age & Gender & $\begin{array}{l}\text { Marital } \\
\text { Status }\end{array}$ & $\begin{array}{l}\text { Academic } \\
\text { Level }\end{array}$ & $\begin{array}{l}\text { Course of } \\
\text { Study }\end{array}$ \\
\hline 1. & The screen resolution of my smartphone is excellent. & 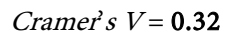 & 0.16 & 0.20 & 0.35 & 0.26 \\
\hline 2. & My smartphone features are easy to understand & Cramer $^{2} s$ V $=0.18$ & 0.30 & 0.20 & 0.28 & 0.187 \\
\hline 3. & $\begin{array}{l}\text { I am always excited to do one thing or the other on my } \\
\text { smartphone because of its attractive features. }\end{array}$ & Cramer's $V=0.23$ & 0.32 & 0.33 & 0.41 & 0.27 \\
\hline 4. & My smartphone allows configuration options and shortcuts. & Cramer $^{2} s$ V $=0.18$ & 0.18 & 0.20 & 0.30 & 0.29 \\
\hline 5. & $\begin{array}{l}\text { My smartphone enhance fast navigation and adequate user } \\
\text { control. }\end{array}$ & Cramer $^{2} s \quad V=0.22$ & 0.21 & 0.10 & 0.19 & 0.19 \\
\hline 6. & My smartphone allows quick visibility and system status. & Cramer ${ }^{2} s=0.21$ & 0.19 & 0.19 & 0.37 & 0.23 \\
\hline 7. & The layout of my smartphone interface is pleasantly varied. & Cramer's $V=0.17$ & 0.34 & 0.16 & 0.18 & 0.28 \\
\hline 8. & $\begin{array}{l}\text { The aesthetic features of my phone influenced my choice at } \\
\text { point of purchase }\end{array}$ & Cramer's $V=0.23$ & 0.10 & 0.16 & 0.20 & 0.31 \\
\hline 9. & $\begin{array}{l}\text { I am always inspired to use my smartphone frequently because } \\
\text { it is visually appealing. }\end{array}$ & Cramer's $V=0.20$ & 0.14 & 0.11 & 0.21 & 0.44 \\
\hline 10. & $\begin{array}{l}\text { The aesthetic features of my smartphone suit my cognitive and } \\
\text { affective needs. }\end{array}$ & Cramer $s$ V $=0.18$ & 0.20 & 0.11 & 0.22 & 0.31 \\
\hline
\end{tabular}

(Source: Researchers, 2017).

\section{Conclusion and Recommendations}

The study has clearly looked into students' perception of the visual aesthetics of their smartphones; as well as considered the demography of students' visual aesthetic judgement. The result interestingly confirmed some assumptions about man and visual aesthetic connection.

Visual aesthetics propels an attraction to a visual object that gives a feeling of a continuous viewing of such object. With the exception of the visually impaired, humans are generally attracted to object with good visual aesthetic properties; the study has revealed this conjecture, as proven by the result of the study carried out on the visual aesthetic quality of smartphone among students. It is therefore glaring from the study that a larger percentage of the students are attracted to using smartphone as a result of the satisfaction they received from the visual quality of the smartphone layout, navigation, as well as the graphical user interface (GUI).

Out of the five (5) demographic factors tested, academic level has the most difference in perception of visual aesthetics while marital status has the least effect; while every other parametric measure returns some level of demographic variations, there is significantly no difference in the respondents' desire for fast navigation of their smartphones and user control.

It is clear that the excellent visual aesthetic quality of smartphones encourages its growing use and desirable incorporation of it into the daily tasks of undergraduates, therefore, care-givers, stakeholders in the education system need to fashion out ways to inculcate greater use of smartphones towards achieving aca- 
demic and other life-centred goals by the students; this demands incorporating it in the learning system. As the students are attracted to the visual aesthetic qualities of the smartphone digital interface, they will also be acquiring knowledge and skills that will help them in their academic pursuit.

This work has contributed to the body of knowledge in the area of delving into the demographic aspects of the visual aesthetics perception in the human-computer interaction field, validates parametric factors for measuring visual aesthetics as well as provide empirical results in smartphone's growing use.

\section{Conflicts of Interest}

The authors declare no conflicts of interest regarding the publication of this paper.

\section{References}

Brachmann, A., \& Redies, C. (2017). Computational and Experimental Approaches to Visual Aesthetics. Frontiers in Computational Neuroscience, 11, 102. https://doi.org/10.3389/fncom.2017.00102

Cohen, J. (1988). Statistical Power Analysis for Behavioural Sciences (2nd ed.). Hillsdale, NJ: L. Erlbaum Associates.

Edelson, P. J. (2011). A Review of Alone Together: Why We Expect More from Technology and Less from Each Other. Stony Brook, NY: State University of New York-Stony Brook.

Frommer, D. (2011). Chart of the Day: Smartphone Sales to Beat PCSales by 2011. http://www.businessinsider.com

Gharaibeh, M., \& Arshad, M. R. M. (2018). The Impact of Demographic Factors and Visual Aesthetics of Mobile Application Interface on Intention to Use Mobile Banking in Jordan. Journal of Theoretical and Applied Information Technology, 96, 937-945.

Hassenzahl, M., \& Tractinsky, N. (2006). User Experience-A Research Agenda. Behaviour \& Information Technology, 25, 91-97. https://doi.org/10.1080/01449290500330331

Ibiwoye, T. I. (2017). Assessment of Photographic Images and Their Effects on Social Networking among Youths in Lagos and Ondo States, Nigeria. An Unpublished PhD Thesis, Akure: Industrial Design Department, Federal University of Technology.

Jollie, N. A., \& Liezel, V. M. (2016). Smartphones Usage among College Students. International Journal of Research in Engineering and Technology, 4, 63-70.

Kubey, R. W., Lavin, M. J., \& Barrows, J. R. (2001). Internet Use and Collegiate Academic Performance Decrements: Early Findings. Journal of Communication, 51, 366-382. https://doi.org/10.1111/j.1460-2466.2001.tb02885.x

Lane, H., Katharina, R., \& Remco, C. (2015). Infographic Aesthetics: Designing for First Impression. In CHI 2015.

Law, E. L., \& Schaik, P. (2010). Modelling User Experience-An Agenda fro Research and Practice. Interacting with Computers, 22, 313-322.

https://doi.org/10.1016/j.intcom.2010.04.006

Lopes, A. M. (2015). Aesthetics, Aesthetic Theories. In C. Edwards (Ed.), Bloomsbury Encyclopaedia of Design (pp. 17-21). London: Bloomsbury.

https://www.researchgate.net/publication/283348334

https://doi.org/10.5040/9781472596178-BED-A021 
Mathieu, Z., \& Jean, V. (2014). Towards an Evaluation of Graphical User iNterfaces Aesthetics Based on Metrics. In IEEE International Conference on Research Challenges in Information Science.

Moss, G. (2003). The Implications of the Male and Female Design Aesthetic for Public Services. The Innovation Journal, 8, Article 4.

Neeru, S. (2012). Meaning of the Term-Descriptive Survey Research Method. International Journal of Transformations in Business Management, 1, 1-7.

Seligman, M. E. P., \& Csikszentmihalyi, M. (2000). Positive Psychology: An Introduction. American Psychologist, 35, 5-14. https://doi.org/10.1037/0003-066X.55.1.5

Shih-Yung, L., \& Hsiu-Tyan, C. (2014). A Study of Aesthetic Factors and Aesthetic Responses of the Interior Environment. International Journal of Research in Humanities, Arts and Literature, 2, 1-8.

Shrestha, S. (2016). Influencing Factors on Consumer Buying Behaviour of Smart Phones-A Research on the Buying Behaviour of Young Consumer in Kathmandu, Nepal. Bachelor's Thesis, International Business Bachelor of Business Administration (BBA).

Tractinsky, N., \& Hassenzahl, M. (2005). Arguing for Aesthetics in Human-Computer Interaction. I-Com, 4, 66-68. https://doi.org/10.1524/icom.2005.4.3.66

Turkle, S. (2011). Alone Together: Why We Expect More from Technology and Less from Each Other. New York: Basic Books.

Yigit, M., \& Halil, S. K. (2015). The Effect of Visual Product Aesthetics on Consumers' Price Sensitivity. Procedia Economics and Finance, 26, 528-534.

https://doi.org/10.1016/S2212-5671(15)00883-7

Zagidullina, M. (2019). The Media-Aesthetic Aspect of Journalism. European Proceedings of Social and Behavioural Sciences, 66, 72-79.

https://doi.org/10.15405/epsbs.2019.08.02.9 